\title{
Disturbance in haematological parameters induced by exposure to electromagnetic fields
}

\begin{abstract}
Background: The use of mobile phones, wireless, and electrical devices has gradually increased throughout the last century, and scientists have suggested that electromagnetic fields (EMFs) generated by such devices may have harmful effects on living creatures. Many studies revealed that the EMFs might produce a variety of adverse effects on human health as headaches, chronic fatigue, heart problems, stress, nausea, chest pain, and also some bad effects on central nervous, endocrine and immune systems. Exposure to EMF result in deterioration of RBCs function and metabolic activity, it was expected that, the increase of toxicity in specific organs was a result of the RBCs functional failure. The mechanisms by which the electromagnetic fields cause their bad effects may be by causing deterioration in cellular large molecules, imbalance in ionic equilibrium and generation of reactive oxygen species (ROS). These reactive oxygen species can damage cellular components such as proteins, lipids and DNA. Measurements of blood parameters are of the most important diagnostic methods by which we can determine the health status of human and animals for certain diseases as anemia, leukemia and also detect the presence of the inflammations.
\end{abstract}

Objectives: This study aimed to present an overview on the previous works from 1997 to 2018 on the varying effects of electromagnetic fields on haematological data in human and different species of experimental models by using different frequencies, intensities, and different sources of electromagnetic fields for different periods. The hematological parameters are fluctuating across the exposure period to the EMFs suggesting the possible induction of hazardous biological effects during the exposure to magnetic field.

Conclusion: It can be concluded that exposure of human and experimental animals to EMFs cause harmful effects on blood cells. These effects were disturbance in haematological parameters depending on species, the sources of EMFs, frequencies, intensities and duration of exposure.

Keywords: haematological changes, RBCs, blood smear, blood indices, WBCs, blood platelets, EMF
Volume 6 Issue 6 - 2018

\author{
JM Jbireal,' Azab Elsayed Azab, ${ }^{2}$ Ata Sedik \\ Ibrahim Elsayed ${ }^{3}$ \\ 'Dean of Faculty of Medicine, Sabratha University, Libya \\ ${ }^{2}$ Head of Physiology Department, Faculty of Medicine, Sabratha \\ University, Libya \\ ${ }^{3}$ Department of Basic Medical Sciences, Inaya Medical College, \\ Saudi Arabia
}

\begin{abstract}
Correspondence: Azab Elsayed Azab, Head of Physiology Department, Faculty of Medicine, Sabratha University, Sabratha, Libya,Email azabelsaied@yahoo.com
\end{abstract} Received: November 01, 2018 | Published: December 28,
2018

\section{Introduction}

The use of electrical devices has gradually increased throughout the last century, and scientists have suggested that electromagnetic fields (EMF) generated by such devices may have harmful effects on living creatures. ${ }^{1,2}$ Since their invention, the telephone has seen much technological advancement up to mobile phones. There are touchtone phones, wireless hand-sets, car-phones, and most recently the cell phone and smart phones have all emerged which are the most widely used recently. ${ }^{3,4}$ The progress of science will provide the world with new electromagnetic fields emitting technologies and subsequently with new problems. Cell phones have become a vital part of everyday life. It creates an electromagnetic fields around them when in use, thus increasing the electromagnetic contamination..$^{5-7}$

Human made Electromagnetic sources are kettles microwaves, refrigerators, washing machines, vacuum cleaners, hair dryers, printers, cellular phones, cables that carry electrical currents, television and computers, electrical home gadgets, radio and television base stations, mobile phone base stations and phone equipment, home wiring airport, and transformers. ${ }^{8}$

Mobile phones, wireless, and electrical devices are the main sources of electromagnetic fields (EMFs). Mobile phones are used in position very close to the human body and require a large number of base station antennas. The resulting health issues have repeatedly been raised by public and scientists. ${ }^{9,10}$

Innovations in cell phones may be associated with detrimental effects on various organs, systems and their functions ${ }^{3,4}$ EMFs might produce a variety of adverse in vivo effects such as chronic fatigue, headaches, cataracts, heart problems, stress, nausea, chest pain, forgetfulness, influence the learning and disturbances in memory, immune systems, and sleep. It has been implicated in adversely affecting multiple facets of human health such as brain, lung and breast tumors, leukemia, genotoxicity, and reproduction anomalies, infertility, increased risk of abortion, birth defects, childhood morbidity, depression, neurodegenerative disease, amyotrophic lateral sclerosis, and Alzheimer's disease. ${ }^{8}$ Previous studies showed that an association between elevated EMFs exposure and mortality of employer in electric utility industry jobs from arrhythmia-related causes and acute myocardial infarction influence heart rate variability by changing autonomic balance. ${ }^{2}$ Exposure to EMFs induces heart palpitations, pain in the chest area, and an irregular heartbeat. Also, exposure to EMFs causes a decreases in total antioxidant capacity and plasma calcium level. Measurements of blood parameters are most important means by which to determine the health status of experimental animals. ${ }^{11,12}$ These measurements are diagnostic for certain diseases such as anemia, leukemia and detect the presence of the inflammation. ${ }^{12,13}$ Researchers have shown that microwave radiation from mobile phone causes harmful effects on blood cells 
in human body. There is increase in red blood cells (RBCs) count, decrease in white blood cell (WBCs) count and lymphocytes count after prolonged exposure to microwave radiation. ${ }^{10}$ Rats exposed to EMF show increases in blood pressure, the whole heart and left ventricular weights. ${ }^{2}$ Movement of hemoglobin in blood vessels is accelerated due to presence of ferric ions. ${ }^{14,15}$

EMFs have various chemical effects, including causing deterioration in large molecules in cells and imbalance in ionic equilibrium. Despite being essential for life, oxygen molecules can lead to the generation of hazardous by-products known as reactive oxygen species (ROS) during biological reactions. These ROS can damage cellular components such as lipids, proteins, and DNA. Antioxidant defense systems exist in order to keep free radical formation under control and to prevent their harmful effects on the biological system. Free radical formation can take place in various ways, including ultraviolet light, immunological reactions, radiation, stress, smoking, and biochemical redox reactions. Oxidative stress (OS) occurs if the antioxidant defense system is unable to prevent the harmful effects of free radicals. Exposure to EMF is known to increase free radical concentrations and trace ability and can affect the radical couple recombination. ${ }^{16}$ Electromagnetic waves have been shown to exert Table I The effect of EMFs on RBCs Count and its indices in human and animals. their effects on biological systems through generation or increase in ROS. ROS, as a medium, contributes to numerous biological impacts including DNA damage and mutation induction. ${ }^{17-19}$ The increase in OS in hematopoietic centers has been reported due to use of mobile phone. ${ }^{18-20}$

\section{Objectives}

This study aimed to present an overview on the previous works from 1997 to 2018 on the varying effects of electromagnetic fields on haematological data in human and different species of experimental models by using different frequencies, intensities, and different sources of electromagnetic fields for different periods.

\section{Effect of EMF on red blood corpuscles and its indices}

Table 1 shows the effect of exposure of experimental animals and human to EMFs from different sources, frequency, and intensity on $\mathrm{RBCs}$ count, $\mathrm{Hb}$ content, $\mathrm{Hct}$ value, $\mathrm{MCV}, \mathrm{MCH}$, and $\mathrm{MCHc}$. Researchers have shown that the electromagnetic fields created by mobile phones and many electronic devices causes harmful effects on red blood cells and its indices in human and experimental animals.

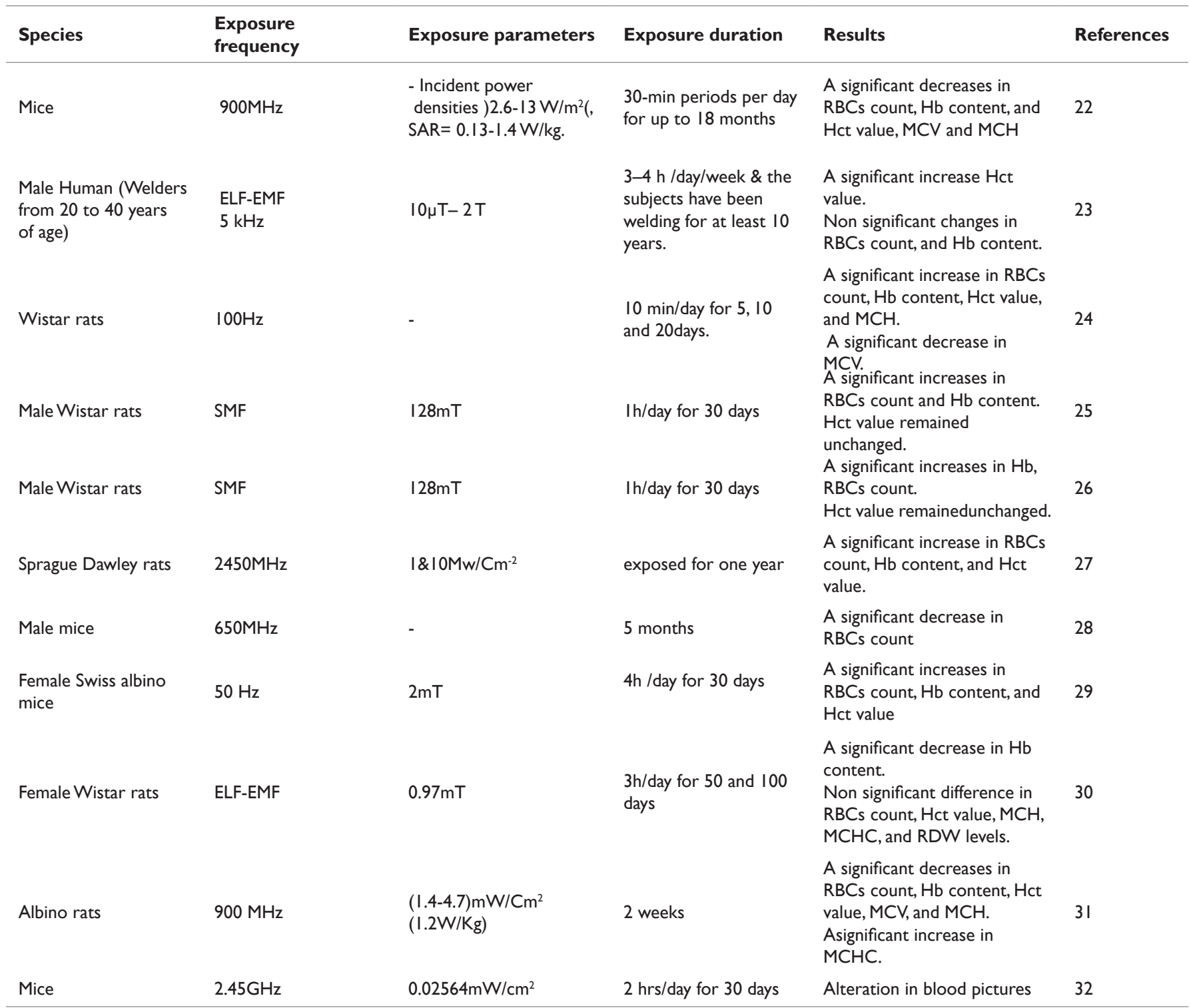


Table Continued....

\begin{tabular}{|c|c|c|c|c|c|}
\hline Species & $\begin{array}{l}\text { Exposure } \\
\text { frequency }\end{array}$ & Exposure parameters & Exposure duration & Results & References \\
\hline Male albino rats & SMF & $2 \mathrm{mT}$ & $\begin{array}{l}60 \text { minutes, } 3 \text { days per } \\
\text { week for two weeks }\end{array}$ & $\begin{array}{l}\text {-After one week, an increase } \\
\text { of RBCs count, Hb content, } \\
\text { and Hct value.A significant } \\
\text { decrease in blood iron. } \\
\text {-After two weeks, a } \\
\text { significant decrease in most } \\
\text { haematological parameters. } \\
\text {-After four weeks, the } \\
\text { haematological parameters } \\
\text { appeared almost normal } \\
\text { and manifested a tendency } \\
\text { towards recovery. }\end{array}$ & 33 \\
\hline Swiss albino mice & $0.9 \mathrm{GHz}$ and $1.8 \mathrm{GHz}$ & $\begin{array}{l}\text { - Field strength }=0.6 \\
x 10^{-3} \mathrm{~mW} / \mathrm{cm}^{2}\end{array}$ & $7 \mathrm{~h} /$ day for 12 weeks. & $\begin{array}{l}\text {-A significant increase in } \\
\text { RBCs count and Hct value, } \\
\text { and a significant decrease in } \\
\text { MCHC. } \\
\text {-In mice exposed to } 1.8 \mathrm{GHz} \text {, } \\
\text { MCH values, Hb content, and } \\
\text { MCV were decreased. } \\
\text {-In mice exposed to } 0.9 \mathrm{GHz} \text {, } \\
\text { MCH, Hb content, and } \mathrm{MCV} \\
\text { values were increased. }\end{array}$ & 34 \\
\hline $\begin{array}{l}\text { Male white } \mathrm{Balb} / \mathrm{c} \\
\text { mice }\end{array}$ & $\begin{array}{l}\text { Mobile phone } \\
\text { (Alcatel\& Nokia) } \\
\text { - } 900 \text { - I800 MHZ }\end{array}$ & $\begin{array}{l}\text { The mobile phone } \\
\text { Alcatel: } 0.49 \mathrm{~W} / \mathrm{kg} \text {. } \\
\text {-The mobile phone } \\
\text { Nokia: } 0.72 \mathrm{~W} / \mathrm{kg} \text {. }\end{array}$ & $\begin{array}{l}\text { - Short term } \\
\text { experiment: I5,30, } 45 \\
\& 60 \mathrm{~min} / \text { day for } 2 \\
\text { weeks } \\
\text { - Long term } \\
\text { experiment: a period } \\
\text { time up to } 90 \mathrm{~min} / \mathrm{day} \\
\text { for I, } 2 \text { \& } 3 \text { months. }\end{array}$ & $\begin{array}{l}\text { - A decline in RBCs count, } \mathrm{Hb} \\
\text { content, and Hct value. }\end{array}$ & 12 \\
\hline Male albino rats & EMF & $202 \mu \mathrm{T}$ & & $\begin{array}{l}\text { A significant increase in RBCs, } \\
\text { and } \mathrm{Hb} \text { as well as decrease in } \\
\text { red blood cell indices values } \\
\text { of } \mathrm{MCV}, \mathrm{MCH} \text { and } \mathrm{MCHC}\end{array}$ & 35 \\
\hline Swiss albino mice & $10 \mathrm{GHz}$ & $\begin{array}{l}0.25 \mathrm{~mW} / \mathrm{cm}^{2} \\
\mathrm{SAR}=0.1790 \mathrm{~W} / \mathrm{Kg}\end{array}$ & $2 \mathrm{~h} /$ day for 30 day. & $\begin{array}{l}\text { An increase in MCV, and a } \\
\text { significant decrease in RBCs } \\
\text { count, } \mathrm{Hb}, \mathrm{Hct}, \mathrm{MCH} \text {, and } \\
\mathrm{MCHC}\end{array}$ & 21 \\
\hline Males mice & $1200 \mathrm{MHz}$ & - & $6 \mathrm{~h} /$ day for 45 days. & $\begin{array}{l}\text {-A significant increase in } \mathrm{RBcs} \\
\text { count. } \\
\text { A significant decrease in } \mathrm{Hb} \text {, } \\
\text { and } \mathrm{Hct} \text {. }\end{array}$ & 36 \\
\hline Male albino rats & $900 \mathrm{MHz}$ & $\begin{array}{l}1.4 \mathrm{~mW} / \mathrm{cm} \\
\mathrm{SAR}=1.2 \mathrm{~W} / \mathrm{kg}\end{array}$ & $\begin{array}{l}2 \mathrm{hrs} / \text { day, } 3 \text { times/week } \\
\text { for } 2 \text { months }\end{array}$ & $\begin{array}{l}\text { A reduction in } \mathrm{RBCs}, \mathrm{Hb}, \mathrm{Hct} \text {, } \\
\mathrm{MCV}, \mathrm{MCH} \text { and } \mathrm{MCHC} \text {. }\end{array}$ & 37 \\
\hline $\begin{array}{l}\text { Human } \\
\text { (young volunteers } \\
\text { more than } 18 \text { year) } \\
\text { - in vitro }\end{array}$ & $\begin{array}{l}\text { Microwave radiation } \\
\text { from mobile phone } \\
\text { (Dual band EGSM } \\
900 / 1800 \mathrm{MHZ})\end{array}$ & - & $\begin{array}{l}\text { Blood sample was } \\
\text { exposed to RF-EMF for } \\
\text { one hour in talk mode } \\
\text { inside the wooden box. }\end{array}$ & $\begin{array}{l}\text { A significant increase in RBCs } \\
\text { count. }\end{array}$ & 10 \\
\hline Male albino rats & $900 \mathrm{MHz}$ & $\begin{array}{l}\text { A peak power of about } \\
60 \mathrm{~W} \text {, power density of } \\
0.05 \mathrm{~mW} / \mathrm{cm}^{2}\end{array}$ & $24 \mathrm{~h} /$ day for 8 Weeks & $\begin{array}{l}\text { a significant reduction } \\
\text { in } \mathrm{RBC} \text { s counts, and } \mathrm{Hb} \\
\text { concentration, meanwhile } \\
\text { reticulocyte count was } \\
\text { elevated }\end{array}$ & 38 \\
\hline Male albino rats & $900 \mathrm{MHz} \& 1.3 \mathrm{GHz}$ & - & $\mathrm{I}, 2,5 \mathrm{~h} /$ day for 28 days & $\begin{array}{l}\text { A significant increase in RBcs } \\
\text { count, } \mathrm{Hb} \text { and } \mathrm{MCH} \\
\text {-The values of RBCs, MCV, } \\
\text { and } \mathrm{Hb} \text { are fluctuating across } \\
\text { the exposure period. } \\
\text {-The values of } \mathrm{MCHC} \\
\text { was decreasing across the } \\
\text { exposure period. }\end{array}$ & 4 \\
\hline
\end{tabular}


Table Continued...

\begin{tabular}{|c|c|c|c|c|c|}
\hline Species & $\begin{array}{l}\text { Exposure } \\
\text { frequency }\end{array}$ & Exposure parameters & Exposure duration & Results & References \\
\hline Adult female rat & $\begin{array}{l}\text { SMF \& mobile } \\
\text { phone } \\
-50-60 \mathrm{~Hz}\end{array}$ & - & $30 \mathrm{~min} /$ day for 45 days & $\begin{array}{l}\text { There were significant } \\
\text { ( } p \leq 0.05 \text { ) decrease in } R B C s \\
\text { count when exposed to } \\
\text { electromagnetic field and } \\
\text { mobile radiation. }\end{array}$ & 39 \\
\hline
\end{tabular}

CW, continuous wave; ELF-EMF, Extremely low frequency electromagnetic fields; GSM, Global System for Mobile Communication; RF-EMF, Radiofrequency electromagnetic fields; SAR, Specific absorption rates; SMF, Static magnetic field

\section{Effects of EMFs on blood smears}

Alghamdi and El-Ghazaly, ${ }^{12}$ investigate the effects of electromagnetic fields on blood smears of male white Balb/c mice. In this study two experiments were used as short-term and long-term experiments. Short-term experiments were carried out in 80 male white Balb/c mice exposed to two types of mobile phone for a period time up to $60 \mathrm{~min}$ a day for 2 weeks. Long-term experiments were carried out in 30 male white Balb/c mice exposed to two types of mobile phone for a period time up to $90 \mathrm{~min}$ a day for a month, two months, three months. Authors found that when exposed male white $\mathrm{Balb} / \mathrm{c}$ mice to both devices (Alcatel, Nokia) for 15 minutes, the red blood cells began to take a role of formation (Figure 1A-B) which may be due to an increase in the viscosity of the blood and the ability of the cells adhesion. Increased duration of exposure to 30-minute to both devices revealed disparities in the sizes of red blood cells with the appearance of a large proportion of cells with pale colors (Figure 1C) which may be due to lack of hemoglobin. In the group exposed for 45 minutes showed clearly the influence of mobile phones on examining blood smears which observed a proportion variation in the cell sizes with the emergence of forms of abnormal forms, including pellets cleft with many areas empty of red blood cells (Figure 1D). With increasing in of exposure duration to 60 minutes, red blood cells appeared completely different from the natural form and took the forms resembling the eye and tear that appear in the case of anemia (Figure 1E). After three months of exposure to both types of mobile phone showed pathological changes in red blood cells where gripped the outer membrane of the red corpuscle changes and become serrated (Figure 1F).

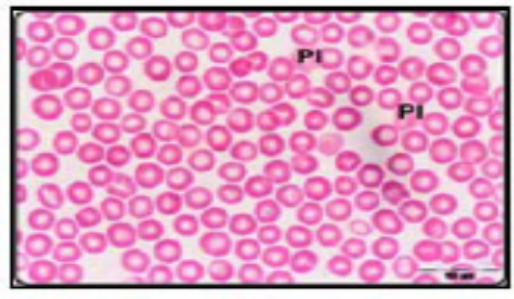

Figure I(A) Blood smear of control group mice, showing nor-mal appearance of erythrocytes and blood platelets (PI) can be seen. Giemsa stain. ${ }^{12}$
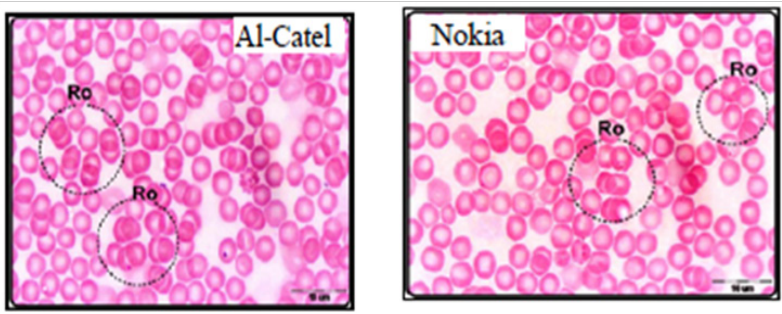

Figure I(B) Blood smear of exposed mice to Al-Catel and Nokia cell phone for 15 minutes, showing Rouleaux erythrocytes (Ro). Giemsa stain. ${ }^{12}$
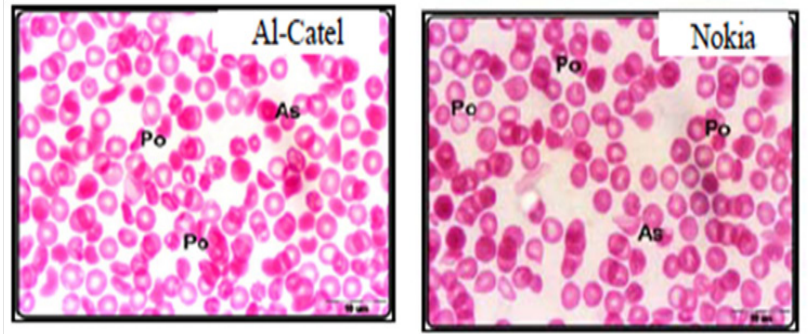

Figure I(C) Blood smear of exposed mice to Al-Catel cell and Nokia phone for 30 minutes, showing Anisocytosis (As) and poikilocytosis of erythrocytes (Po), as well as pale corpuscles can be seen. Giemsa stain. ${ }^{12}$
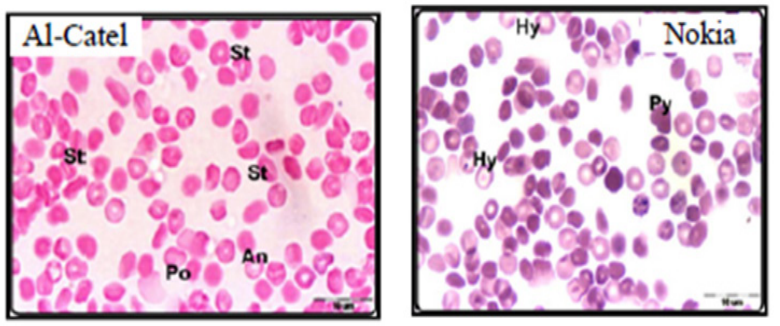

Figure I(D) Blood smear of exposed mice to Al-Catel and Nokia cell phone for 45 minutes, showing Poikilocytosis (Po) Anisochromia (An) and Stom atocytosis (St) erythrocytes. Giemsa stain. ${ }^{12}$
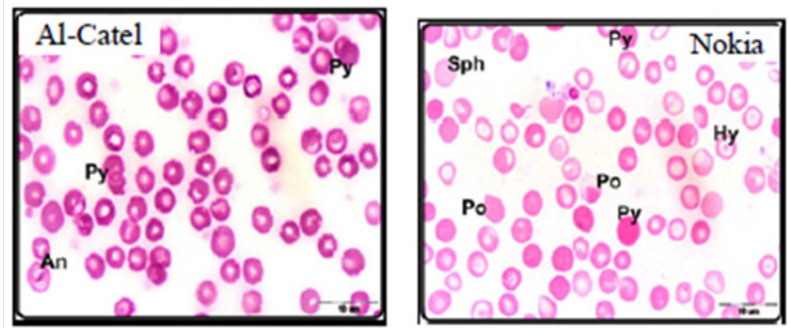

Figure I (E) Blood smear of exposed mice to Al-Catel and Nokia cell phone for 60 minutes, showing Polychromic (Py) and Anisochromia (An) erythrocytes. Giemsa stain. ${ }^{12}$
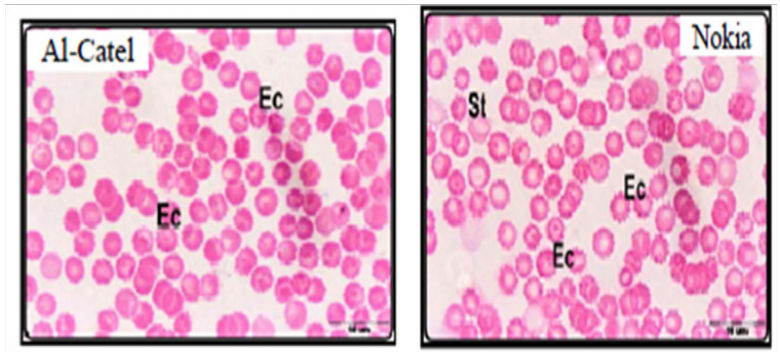

Figure I (F) Blood smear of exposed mice to Al-Catel and Nokia cell phone after three months of exposure, showing large number of Echinocytic erythrocytes (Ec). Giemsa stain. ${ }^{12}$ Blood smear of control and exposed mice to Al-Catel and Nokia cell phone after 15, 30, 45 \& 60 minutes, and three months of exposure, A, B, C, D, E \& F, respectively (Giemsa stain). ${ }^{12}$ 


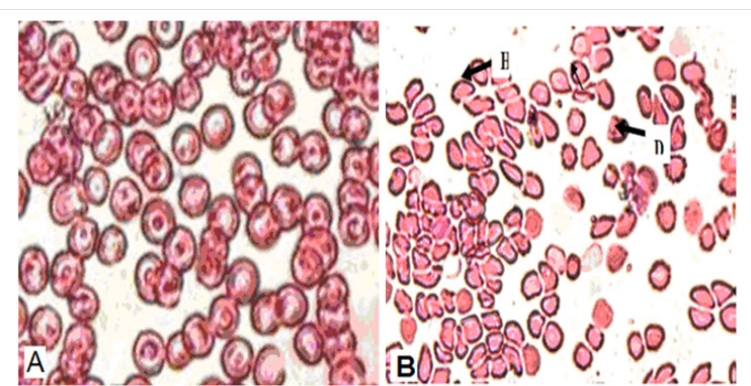

Figure 2 (A) Geimsa stained blood smear of mice of sham exposed mice, showing normal appearance of erythrocytes. (I00xmagnification). (B) Geimsa stained blood smear of MW exposed mice showing hemolysed $(\mathrm{H})$ and distorted (D) erythrocytes with abnormal blood smear (I00xmagnification). ${ }^{21}$

The study of Rifat et al., ${ }^{21}$ showed that microscopic examination of blood smears of Swiss albino mice exposed to10 $\mathrm{GHz}$ microwave (MW) with the power density of $0.25 \mathrm{~mW} / \mathrm{cm}^{2}$ with average whole body specific absorption rate $0.1790 \mathrm{~W} / \mathrm{kg} / \mathrm{day}$ for $2 \mathrm{~h} /$ day for 30 day caused a modifications in the shape and size of the erythrocytes representing morphologic abnormality as compared with unexposed mice to MW (Figure 2). Poikilocytosis, spherocytosis, hemolysed and distorted erythrocytes seen in MW exposed mice may be due to the formation of active loci on the red blood cell membrane as a result of interaction with free radicals thereby resulting in the alteration of shape of erythrocytes. ${ }^{21}$

\section{Effects of EMFs on leukocytes}

The effects of EMFs on WBCs count, lymphocytes \%, neutrophils $\%$, eosinophils $\%$, basophils $\%$, and monocytes $\%$ in human and experimental animals are shown in Table 2.

\section{Effects of EMFs on blood platelets}

Table 3 shows the effect of EMFs on blood platelets count in human and experimental animals.

Table 2 The effect of EMFs on WBCs Count and Differential Count in human and animals

\begin{tabular}{|c|c|c|c|c|c|}
\hline Animal species & Exposure frequency & Exposure parameters & Exposure duration & Results & References \\
\hline $\begin{array}{l}\text { Male Human } \\
\text { (Welders from } 20 \\
\text { to } 40 \text { years of age) }\end{array}$ & $\begin{array}{l}- \text { ELF-EMF } \\
-5 \mathrm{kHz}\end{array}$ & $10 \mu \mathrm{T}-2 \mathrm{~T}$ & $\begin{array}{l}3-4 \mathrm{~h} / \text { day/week } \\
- \text { The subjects have been } \\
\text { welding for at least } 10 \text { years. }\end{array}$ & $\begin{array}{l}\text {-Insignificant changes in } \\
\text { WBCs count, neutrophils, } \\
\text { lymphocytes, and eosinophils }\end{array}$ & 23 \\
\hline Wistar rats & $\mathrm{I0OHz}$ & - & $\begin{array}{l}10 \mathrm{~min} / \text { day for } 5,10 \text { and } 20 \\
\text { days. }\end{array}$ & $\begin{array}{l}\text { The total leucocytes number } \\
\text { fluctuated: decrease at } 5 \text { and } \\
20 \text { days and increase at } 10 \\
\text { days of treatment. }\end{array}$ & 24 \\
\hline Male Wistar rats & SMF & $128 \mathrm{mT}$ & Ih/day for 30days & $\begin{array}{l}\text { A significant increase in } \\
\text { WBCs count. }\end{array}$ & 25 \\
\hline \multirow[t]{2}{*}{ Male Wistar rats } & SMF & $128 \mathrm{mT}$ & Ih/day for 30days & $\begin{array}{l}\text { A significant increase in } \\
\text { WBCs count. }\end{array}$ & 26 \\
\hline & & & & $\begin{array}{l}\text { A significant decrease in } \\
\text { Eosinophils in rats that were } \\
\text { exposed to EMF for } 50 \text { days. }\end{array}$ & \\
\hline Female Wistar rats & ELF-EMF & $0.97 \mathrm{mT}$ & $3 \mathrm{~h} /$ day for 50 and 100 days & $\begin{array}{l}\text { - Non significant difference } \\
\text { in WBCs, neutrophil, } \\
\text { lymphocyte, monocyte, and } \\
\text { basophil counts. }\end{array}$ & 30 \\
\hline $\begin{array}{l}\text { Female Swiss albino } \\
\text { mice }\end{array}$ & $50 \mathrm{~Hz}$ & $2 \mathrm{mT}$ (=20 Gauss) & (4h /day) for 30 days & $\begin{array}{l}\text {-Leukocytosis with } \\
\text { neutrophilia, lymphocytosis, } \\
\text { and monocytosis } \\
\text {-A significant increased in } \\
\text { the phagocytosis \% and } \\
\text { phagocytic index. }\end{array}$ & 29 \\
\hline Albino rats & $900 \mathrm{MHz}$ & $\begin{array}{l}(\mathrm{I} .4-4.7) \mathrm{mW} / \mathrm{Cm}^{2} \\
(\mathrm{I} .2 \mathrm{~W} / \mathrm{Kg})\end{array}$ & 2 weeks & $\begin{array}{l}\text {-A significant increase } \\
\text { in WBCs count and } \\
\text { lymphocytes \% }\end{array}$ & 31 \\
\hline Male albino rats & SMF & $2 \mathrm{mT}$ & $\begin{array}{l}60 \mathrm{~min} / \text { day ( } 3 \text { days per week) } \\
\text { for two weeks }\end{array}$ & $\begin{array}{l}\text { A significant increase in } \\
\text { WBCs count . } \\
\text {-After thirty days following } \\
\text { magnetic exposure, the } \\
\text { white blood cells count } \\
\text { appeared almost normal } \\
\text { and manifested a tendency } \\
\text { towards recovery. }\end{array}$ & 33 \\
\hline $\begin{array}{l}\text { Male white Balb/c } \\
\text { mice }\end{array}$ & $\begin{array}{l}\text { Mobile phone (Alcatel } \\
\text { and Nokia) } \\
-900-1800 \mathrm{MHZ}\end{array}$ & $\begin{array}{l}\text { The mobile phone } \\
\text { Alcatel:0.49W/kg. } \\
\text {-The mobile phone } \\
\text { Nokia: } 0.72 \mathrm{~W} / \mathrm{kg} \text {. }\end{array}$ & $\begin{array}{l}\text {-Short term experiment: } \\
\text { I5,30, } 45 \& 60 \mathrm{~min} \text { a day for } \\
2 \text { weeks } \\
\text {-Long term experiment: a } \\
\text { period time up to } 90 \mathrm{~min} / \\
\text { day for I, } 2 \& 3 \text { months. }\end{array}$ & $\begin{array}{l}\text { A significant increase in } \\
\text { WBCs and lymphocytes } \\
\text { count. }\end{array}$ & 12 \\
\hline
\end{tabular}


Table Continued....

\begin{tabular}{|c|c|c|c|c|c|}
\hline Animal species & Exposure frequency & Exposure parameters & Exposure duration & Results & References \\
\hline Swiss albino mice & $0.9 \mathrm{GHz} \& 1.8 \mathrm{GHz}$ & $0.6 \times 10^{-3} \mathrm{~mW} / \mathrm{cm}^{2}$ & $7 \mathrm{~h} /$ day for 12 weeks. & $\begin{array}{l}\text { A significant decrease in } \\
\text { WBCs count. }\end{array}$ & 34 \\
\hline Male albino rats & $\begin{array}{l}\text { the electromagnetic } \\
\text { field }\end{array}$ & $202 \mu \mathrm{T}$ & & $\begin{array}{l}\text { A significant increase in } \\
\text { WBCs count. }\end{array}$ & 35 \\
\hline Swiss albino mice & $10 \mathrm{GHz}$ & $\begin{array}{l}0.25 \mathrm{~mW} / \mathrm{cm}^{2}(0.1790 \\
\mathrm{W} / \mathrm{Kg})\end{array}$ & $2 \mathrm{~h} /$ day for 30 day. & $\begin{array}{l}\text { A significant increase } \\
\text { in WBCs count, and } \\
\text { lymphocytes \%, and a } \\
\text { significant decrease in } \\
\text { monocytes \%. }\end{array}$ & 21 \\
\hline Males mice & $1200 \mathrm{MHz}$ & - & $6 \mathrm{~h} /$ day for 45 days. & $\begin{array}{l}\text {-A significant increase in } \\
\text { WBCs count, lymphocytes, } \\
\text { monocytes and acidophils. } \\
\text {-A significant decrease in } \\
\text { neutrophils. }\end{array}$ & 36 \\
\hline Male albino rats & $900 \mathrm{MHz}$ & $\begin{array}{l}1.4 \mathrm{~mW} / \mathrm{cm} \\
1.2 \mathrm{w} / \mathrm{kg}\end{array}$ & $\begin{array}{l}2 \mathrm{hrs} / \text { day, } 3 \text { times/week for } 2 \\
\text { months }\end{array}$ & $\begin{array}{l}\text {-A significant increase in } \\
\text { WBCs count, lymphocytes \% } \\
\text {, and neutrophil \%. }\end{array}$ & 37 \\
\hline Human & $\begin{array}{l}\text { Microwave radiation } \\
\text { from mobile phone }\end{array}$ & - & Prolonged exposure & $\begin{array}{l}\text {-A significant decrease in } \\
\text { WBCs and lymphocytes } \\
\text { count. }\end{array}$ & 10 \\
\hline Male albino rats & $900 \mathrm{MHz}$ & $\begin{array}{l}\text { A peak power of about } \\
60 \mathrm{~W}, \text { power density of } \\
0.05 \mathrm{~mW} / \mathrm{cm}^{2}\end{array}$ & $24 \mathrm{~h} /$ day for 8 Weeks & $\begin{array}{l}\text { - Leukocyte counts was not } \\
\text { affected by exposure }\end{array}$ & 38 \\
\hline Male albino rats & $900 \mathrm{MHz} \& 1.3 \mathrm{GHz}$ & - & $\mathrm{I}, 2,5 \mathrm{~h} /$ day for 28 days & $\begin{array}{l}\text {-Lymphocytes are fluctuating } \\
\text { across the exposure period. } \\
\text { - A significant decrease in } \\
\text { WBC count }\end{array}$ & 4 \\
\hline Adult female rat & $\begin{array}{l}\text { SMF and mobile } \\
\text { phone radiation } \\
50-60 \mathrm{~Hz}\end{array}$ & - & $30 \mathrm{~min} /$ day for 45 days & $\begin{array}{l}\text { A significant }(p \leq 0.05) \\
\text { increase in } W B C \text { when were } \\
\text { exposed to electromagnetic } \\
\text { field. While there were a } \\
\text { significant }(p \leq 0.05) \text { decrease } \\
\text { in WBC when female rats } \\
\text { were exposure to mobile } \\
\text { phone radiation. }\end{array}$ & 39 \\
\hline
\end{tabular}

CW, continuous wave; ELF-EMF, Extremely low frequency electromagnetic fields; GSM, Global System for Mobile Communication; RF-EMF, Radiofrequency electromagnetic fields; SAR, Specific absorption rates; SMF, Static magnetic field

Table 3 The effect of EMFs on Blood platelets Count in human and animals

\begin{tabular}{|c|c|c|c|c|c|}
\hline Animal species & Exposure frequency & Exposure parameters & Exposure duration & Results & References \\
\hline $\begin{array}{l}\text { Male Human } \\
\text { (Welders from } \\
20 \text { to } 40 \text { years of } \\
\text { age) }\end{array}$ & $\begin{array}{l}=\quad \text { ELF-EMF } \\
=\quad 5 \mathrm{kHz}\end{array}$ & $10 \mu T-2 T$ & $\begin{array}{l}3-4 \text { h per day. } \\
\text { The subjects in } \\
\text { The experimental group } \\
\text { have been welding for at } \\
\text { least } 10 \text { years. }\end{array}$ & $\begin{array}{l}\text { Insignificant changes in } \\
\text { platelets count. }\end{array}$ & 23 \\
\hline Male Wistar rats & SMF & $128 \mathrm{mT}$ & Ih/day for 30 days & An increase in platelet count. & 25 \\
\hline Male Wistar rats & SMF & $128 \mathrm{mT}$ & $\mathrm{Ih} /$ day for 30 days & An increase in platelet count. & 26 \\
\hline $\begin{array}{l}\text { Female Wistar } \\
\text { rats }\end{array}$ & ELF-EMF & $0.97 \mathrm{mT}$ & $3 \mathrm{~h} /$ day for 50 and 100 days & $\begin{array}{l}\text { Non significant changes in } \\
\text { platelet count and PDW } \\
\text { levels. } \\
\text {-A significant decrease in MPV. }\end{array}$ & 30 \\
\hline $\begin{array}{l}\text { Female Swiss } \\
\text { albino mice }\end{array}$ & $50 \mathrm{~Hz}$ & $2 \mathrm{mT}$ (=20 Gauss) & (4h/day) for 30 days & $\begin{array}{l}\text { An increase in the blood } \\
\text { platelets count. }\end{array}$ & 29 \\
\hline Albino rats & $900 \mathrm{MHz}$ & $\begin{array}{l}(1.4-4.7) \mathrm{mW} / \mathrm{Cm}^{2} \\
(\mathrm{I} .2 \mathrm{~W} / \mathrm{Kg})\end{array}$ & 2 weeks & $\begin{array}{l}\text { - A significant increase in the } \\
\text { blood platelets count }\end{array}$ & 31 \\
\hline
\end{tabular}


Table Continued....

\begin{tabular}{|c|c|c|c|c|c|}
\hline Animal species & Exposure frequency & Exposure parameters & Exposure duration & Results & References \\
\hline Male albino rats & SMF & $2 \mathrm{mT}$ & $\begin{array}{l}60 \text { minutes, } 3 \text { days per week } \\
\text { for two weeks }\end{array}$ & $\begin{array}{l}\text { A significant increase in the } \\
\text { blood platelets count. } \\
\text { - After thirty days following } \\
\text { magnetic exposure, the blood } \\
\text { platelets count appeared } \\
\text { normal and manifested a } \\
\text { tendency towards recovery }\end{array}$ & 33 \\
\hline $\begin{array}{l}\text { Male white Balb/c } \\
\text { mice }\end{array}$ & $\begin{array}{l}\text { Exposed mice to two } \\
\text { types of mobile phone } \\
\text { (Alcatel and Nokia) } \\
\text { separately } \\
\text { - } 900 \text { - I } 800 \mathrm{MHZ}\end{array}$ & $\begin{array}{l}\text { The mobile phone } \\
\text { Alcatel: } 0.49 \mathrm{~W} / \mathrm{kg} \text {. } \\
\text {-The mobile phone } \\
\text { Nokia: } 0.72 \mathrm{~W} / \mathrm{kg} \text {. }\end{array}$ & $\begin{array}{l}\text {-Short term experiment: } \\
\text { I5,30, } 45 \text { \& } 60 \mathrm{~min} / \text { day for } \\
2 \text { weeks } \\
\text {-Long term experiment: up } \\
\text { to } 90 \mathrm{~min} / \text { day for I, } 2 \text { \&3 } \\
\text { months. }\end{array}$ & $\begin{array}{l}\text { A decline in the platelets } \\
\text { count. }\end{array}$ & 12 \\
\hline Male albino rats & $\begin{array}{l}\text { the electromagnetic } \\
\text { field }\end{array}$ & $202 \mu \mathrm{T}$ & & $\begin{array}{l}\text { A significant increase in } \\
\text { platelet count }\end{array}$ & 35 \\
\hline Male albino rats & $900 \mathrm{MHz}$ & $\begin{array}{l}\mathrm{I} .4 \mathrm{~mW} / \mathrm{cm}^{2} \\
\mathrm{I} .2 \mathrm{w} / \mathrm{kg}\end{array}$ & $\begin{array}{l}2 \mathrm{hrs} / \text { day, } 3 \text { times / week for } \\
2 \text { months }\end{array}$ & $\begin{array}{l}\text { An increase in the platelets } \\
\text { count }\end{array}$ & 37 \\
\hline Male albino rats & $\begin{array}{l}\text { electromagnetic field, } \\
\text { emitted from a cellular } \\
\text { tower for mobile } \\
\text { phone } 900 \mathrm{MHz}\end{array}$ & $\begin{array}{l}\text { A peak power of about } \\
60 \mathrm{~W} \text {, power density of } \\
0.05 \mathrm{~mW} / \mathrm{cm}^{2}\end{array}$ & $24 \mathrm{~h} /$ day for 8 Weeks & $\begin{array}{l}\text { - Blood platelets count was } \\
\text { not affected by exposure. }\end{array}$ & 38 \\
\hline
\end{tabular}

CW, continuous wave; ELF-EMF, extremely low frequency electromagnetic fields; GSM, global system for mobile communication; RF-EMF, radiofrequency electromagnetic fields; SAR, specific absorption rates; SMF, static magnetic field

\section{Discussion}

EMF had a different influence on RBCs and leucocytes Count. A such an effect can be determined by a selective action of EMF on haematopoietic processes and the cell maturation rhythm and on sanguine reservoir. ${ }^{24}$ Interpretation of EMR effect on blood and blood forming systems depends to a great degree on the absorption of biological material and thermoregulatory system of the irradiated individual. ${ }^{40,41}$ Many of previous researches reported that exposure of some experimental models to EMF caused a decrease in RBCs count and its indices. ${ }^{12,21,22,28,37-39}$ The decrease in RBCs count in animals exposed to EMF can be explained by the effect of EMR on the haematopoietic system which is susceptible to be damaged by radiation and that the high mitotic activity of the bone marrow make it the most vulnerable organ system to the effect of radiation. ${ }^{38,42,43}$ This decline is an indication of different types of anemia (Singh et al. 1995). These findings were further confirmed histopathologically in the spleen which showed splenic sinusoids with hemorrhagic or/ and hemolysed blood and an increase of hemosiderin granules. ${ }^{33}$ This may arise under the influence of exposure to radiation, increased temperature and body resistance. ${ }^{12}$ The depletion in the values of hematological parameters (RBCs, Hb, Hct, MCV, MCH and MCHC) following EMF radiation exposure may be attributed to direct damage caused by radiation and due to overproduction of ROS by microwave radiation interaction ${ }^{21,37,44}$ and inhibition by free radicals produced by MW interactions. ${ }^{21}$ The effects of free radicals on the red blood cell membrane and cytoskeleton may contribute to the leak of hemoglobin out of the cells..$^{36,37,45-48}$ The hemolysis of the red blood cells reflects the loss of integrity of the cells which can lead to the liberation of intracellular hemoglobin. ${ }^{37,47}$ Haemolytic disorders may be caused by many factors including physical agents. ${ }^{38,49}$ The haemolytic anaemia results primarily from increased red cell destruction $^{38,50}$ which stimulates erythropoiesis. The evaluation of suspected haemolytic states should include measures of increased red cell destruction and parameters of accelerated erythropoiesis which is measured by the reticulocyte count. These results could be explained on the base of EMR exposure may be responsible for the changes of blood and glutathione enhancer can provide protection against the effect of EMR of MBS. ${ }^{51,52}$ Radiation was reported to cause oxidation of the sulphydryl groups and induce conformational changes of membrane proteins..$^{37,53}$ The hypothesis of an action of SMF on the geometrical conformation of haemoglobin was reinforced by the fact that SMF induced a prominent effect on the haemoglobin structure as previously demonstrated by Amara et al., ${ }^{26}$ and Zaghloul. ${ }^{33}$ Exposure to moderate and strong SMF induced change in the absorption spectra and conductivity measurements of hemoglobin molecules, globin unfolding i.e. a sign of molecular destabilization. This reflects the function of haemoglobin which would be converted from oxyhaemoglobin to non functional met haemoglobin with decreasing oxygen affinity. ${ }^{33,54}$ The SMF may cause cardiovascular stress accompanied with a slow development of mild cardiac decompensation during the exposure period, hence developing heart failure with subsequent passive congestion and stagnant hypoxia. ${ }^{33,55}$ Thus, the body adapts to the higher oxygen needs, more fluid would be in the blood. In turn, measured haemoglobin in such cases would be apparently low. This is because it was diluted out by a larger plasma volume. Moreover, the red blood cells looked normal on the blood smear although haemoglobin, serum iron and haematocrit values were significantly decreased, hence resulted in anemia. Usually, this type of anemia is mild and appears like the pseudo-anemia caused by sports. In this respect, regular physical activity, especially extensive running and exercises increase iron loss causing mild iron deficiency. ${ }^{33,56}$

Packed cells volume was a significant decrease as compared with the control group, which can be explained as due to a significant decrease in $\mathrm{Hb}$, this would lead to decrease in the size of RBCs and hence a final decrease in PCV. ${ }^{36}$

The decrease in blood iron could be attributed to the interaction between heme (iron) and SMF where the magnetic field penetrates the body and acts on ions in all organs, altering the cell membrane 
potential and distribution of ions. ${ }^{33,57}$ It is well documented that transferrin controlled transit of iron since intestinal enterocytes increase medullar erythroblasts and allowed recovery of iron after destruction of erythrocytes by macrophagic system. ${ }^{33,58}$

On the other hand, other researches reported that a significant increase in RBCs count, and most of RBCs indices were recorded after exposure of different species of animals to EMFs. , $10,24-27,29,33-36^{-1}$ Thus, indicating that long time exposure might pose detrimental effects to blood components and their functions. ${ }^{4}$

Exposure to EMF result in deterioration of RBCs function and metabolic activity, it was expected that, the increase of toxicity in specific organs was a result of the RBCs functional failure. Therefore, changes in antioxidants may be due to the deterioration in cellular membrane properties in the liver. In addition to increase toxicity in different organs. ${ }^{27,59}$ Magnetic field exposure has been reported to increase the immature and mature erythrocytes in mice..$^{15,60}$ These changes suggesting the hypoxia-like status resulting probably from the oxygen-binding impairment of $\mathrm{Hb}$ which in turn associates with increased oxidative stress. ${ }^{26,29,36,61-63}$

Hemoglobin content record an increase values according to increasing of $\mathrm{MCH}$ values, indicating a better level of respiratory performances of RBCs count as a result of EMF action. The increasing of hemoglobin values takes places especially by an increase of $\mathrm{MCH}$ and less by an increase of RBCs count. This effect assume a hemoglobin synthesis stimulation by EMF. MCV recorded low values, possible owing to an effect of EMF on membrane permeability with a lost of the cellular water and a cellular volume reducing. This effect is accompanied by the $\mathrm{MCH}$ increase with preserve of cellular respiratory capacity. ${ }^{24}$

Many of previous studies showed that exposure of some experimental models to EMF caused a significant increase in WBCs count and some differential WBC counts over time. ${ }^{12,21,25,26,29,31,33,35,36}$ ,39,64 Elevated WBC count might reflect inflammation. ${ }^{29}$ A significant increase in white blood cells count were accompanied by enlargement of the white pulp masses was detected one day after the end of exposure to SMF. It is clear that a splenic white pulp represents an active site of lymphocytic cell proliferation. ${ }^{33}$ The significant increase in total WBCs count comes from the significant high increase in lymphocytes which is due to the harmful action of electromagnetic waves exposure that stimulates the haemopoietic system to release more lymphocytes causing an increase in their number in the blood stream..$^{21,31,36,37}$

Abdel Aziz et al., ${ }^{31}$ reported that a significant increase in lymphocytes in cases of macrocytic anemia, which arise under the influence of exposure to radiation, increased temperature, and increased resistance to the body's immune system. The increase in the lymphocytes \% may be associated with lymphatic leukemia or inflammation of the lymph gland which will appear as a result of constant exposure to electromagnetic waves. ${ }^{65-67}$ These results were confirmed by lymphoid depletion in some splenic white pulps and the others became hyperplastic. ${ }^{29}$

Exposure to EMFs caused a significant decrease in neutrophils, ${ }^{36,68}$ which might be due to the absolute increase in lymphocytes (lymphocytosis). ${ }^{36}$

On the other hand, other researchers reprted that exposure of experimental animals to EMFs caused a significant decrease in WBCs count. ${ }^{4,10,15,34,69-71}$
Bonhomme- Faivre et al. ${ }^{69}$ reported a decline in lymphocytes, monocytes and eosinophils in mice depending on the duration of exposure to magnetic field. Also, it has been reported that chronic exposure to a $0.2-6.6-\mu \mathrm{T}$ magnetic field can lead to decreased total lymphocytes in humans and mice..$^{15,72}$

Most of the previous studies reported that exposure of experimental animals to EMFs resulted in a significant increase in blood platelets count. $25,26,29,31,33,35,37$ These results were confirmed by proliferation of megakaryocytes, precursor cells of blood platelets..$^{29,33,73}$ The increase in megakaryocytes may lead to increased blood platelets which were observed..$^{37}$

The variation in the haematological parameters can be attributed to the differences in the frequency of EMF used and/ or duration and time of exposure, the mitotic rate of the exposed cell population and the differences in animal species used. ${ }^{38,74}$

\section{Conclusion}

It can be concluded that exposure of human and experimental animals to EMFs has been causes harmful effects on blood cells. These effects were disturbance in haematological parameters depending on species, the sources of EMFs, frequencies, intensities and duration of exposure. The EMFs exposure guidelines also need to be updated or reconsidered as new scientific information on EMF and the haematological parameters is produced. However, additional studies might increase our understanding of the sensitivity of haematopieses to EMFs.

\section{Acknowledgments}

None.

\section{Conflicts of interest}

Author declares that there is no conflicts of interest.

\section{References}

1. Elmas O. Effects of electromagnetic field exposure on the heart: a systematic review. Toxicol Ind Health. 2016;32(1):76-82.

2. Azab AE, Ebrahim SA. Exposure to electromagnetic fields induces oxidative stress and pathophysiological changes in the cardiovascular system. J Appl Biotechnol Bioeng. 2017;4(2):540-545.

3. Durney $\mathrm{CH}$, Iskander $\mathrm{MF}$, Massoudi $\mathrm{H}$, et al. Biological effect of electromagnetic radiation. New York Ieee Press. 1984. p. 85-90.

4. Sani A, Labaran MM, Dayyabu B. Effects of electromagnetic radiation of mobile phones on hematological and biochemical parameters in male albino rats. European J Exper Biol. 2018;8(2):11.

5. Pourlis AF. Reproductive and developmental effects of EMF in vertebrate animal models. Pathophysiol. 2009;16:179-189.

6. Agarwal A, Singh A, Hamada A, et al. Cell phones and male infertility: A review of recent innovations in technology and consequences. Inter Braz J Urol. 2011;37(4):432-454.

7. Azab AE, Khalat AM, Ebrahim SA, et al. Electromagnetic fields and its harmful effects on the male reproductive system. Biosci Bioeng. 2018;4(1):1-13.

8. Ebrahim S, Azab AE, Albasha MO, et al. The biological effects of electromagnetic fields on human and experimental animals. Inter Res $J$ Nat Appl Sci. 2016;3(10):106-121.

9. Atasoy A, Sevim Y, Kaya L, et al. The effect of electromagnetic field 
on peripheral blood mononuclear cells in vitro. Bratisl Lek Listy. 2009;110(9):526-529.

10. Kumari P, Manjula SD, Gautham K. In Vitro study of effect of radiation emitted by mobile phone on osmotic fragility and other blood parameters. Res J Pharm Biol Chem Sci. 2016;7(4):1283-1292.

11. Soud R. Human and the environment (education study of the environment) Dar Al-Hamed for publication and distribution," J Environ Stud. 2004;1:23-31.

12. Alghamdi MS, El-Ghazaly NA. Effects of exposure to electromagnetic field on some hematological parameters in mice. Open J Med Chem. 2012;2:30-42.

13. Fatayer AR. Hematology (Theoretical and practical) culture library house for publication and distribution. J Environ Stud. 2006;2:223-229.

14. Bansal HL. Magnetic therapy. 2006.

15. Jain N, Shedpure M, Tikariha R, et al. Review article magnetic field effect on biological system. Indian J Life Sci. 2015;5(1):135-151.

16. Kivrak EG, Yurt KK, Kaplan AA, et al. Effects of electromagnetic fields exposure on the antioxidant defense system. J Microscopy Ultrastruc. 2017;5(4):167-176.

17. Okano H. Effects of static magnetic fields in biology: Role of free radicals. Front Biosci. 2008;13(1):610-625.

18. Baharara J, Zafar-Balanejad S, Kamareh E, et al. The effects of green tea extract on teratogenicity induced by low frequency electromagnetic field on bone marrow Balb/C mice embryo. J Herb Med Pharmacol. 2014;3(1):47-51.

19. Azab AE, Ebrahim SA. Bioeffects induced by exposure to electromagnetic fields and mitigation by natural antioxidants. SAS J Med. 2016;2(6):126-133.

20. Mostafa YM, Mostafa RM, Belacy A, et al. Effect of acute exposure to the radiofrequency field of cellular phones on plasma lipid peroxide and antioxidase activities in human erythrocytes. J Pharm Biomed Anal. 2001;26(4):605-608.

21. Rifat F, Saxena VK, srivastava P, et al. Effects of $10 \mathrm{GHz}$ MW exposure on hematological changes in Swiss albino mice and their modulation by Prunus domestica fruit extract. Inter J Advan Res. 2014;2(2):386-397.

22. Repacholi MH, Basten A, Gebski V, et al. Lymphomas in E $\mu$-Pim1 transgenic mice exposed to pulsed $900 \mathrm{MHz}$ electromagnetic fields. Rad Res. 1997;147:631-640

23. Dasdag S, Sert C, Akdag Z, et al. Effects of extremely low frequency electromagnetic fields on hematologic and immunologic parameters in welders. Arch Med Res. 2002;33:29-32.

24. Neacsu IV, Maniu CL, Hritcu LG. Effects of an weak electromagnetic field upon rat blood parameters. Scientific Annals of "Alexandru Ioan Cuza” University of Iasi (New Series). Genetics Mole Biol. 2005;2(A):6.

25. Salem A, Hafedh A, Rached A, et al. Zinc prevents hematological and biochemical alterations induced by static magnetic field in rats. Pharmacol Rep. 2005;57:616-622.

26. Amara S, Abdelmelek H, Ben Salem M, et al. Effects of static magnetic field exposure on hematological and biochemical parameters in rats. Brazilian Arch Biol Technol. 2006;49(6):889-895.

27. Esfahani SM, Radmehr B, Kohbodi A. Detection of portable effects of Microwave exposure of blood parameters of RBC, PCV and $\mathrm{Hb}$ in rat. Pak J Biol Sci. 2007;10(24):4567-4569.

28. Rusnani A, Norhayati MN, Noraini SS, et al. Microwave radiation effect-A test on white mice. International RF and Microwave Conference. 2008 .
29. Hashem MA, El-Sharkawy NI. Hemato-biochemical and immunotoxicological effects of low electromagnetic field and its interaction with lead acetate in mice. Iraqi $J$ Veter Sci. 2009;23(1):105-114.

30. Cakir DU, Yokus B, Akdag MZ, et al. Alterations of hematological variations in rats exposed to extremely low frequency magnetic fields (50 Hz). Arch Med Res. 2009;40;352-356.

31. Abdel Aziz I, El-Khozondar HJ, Shabat M, et al. Effect of electromagnetic field on body weight and blood indices in albino rats and the therapeutic action of vitamin C or E. Romanian J Biophys. 2010;20(3):235-244.

32. Chaturvedi CM, Singh VP, Singh P, et al. $2.45 \mathrm{GHz} \mathrm{CW}$ microwave irradiation alters circadian organization, spatial memory, DNA structure in the brain cells and blood cell counts of male mice, Mus musculus. Progress Electromag Res. 2011;29:23-42.

33. Zaghloul MS. Effects of chronic exposure to static electromagnetic field on certain histological aspects of the spleen and some haematological parameters in albino rats. J Amer Sci. 2011;7(8):383-394.

34. Usman AD, Ahmad WW, Kadir MZ, et al. Effect of radiofrequency electromagnetic field exposure on hematological parameters of mice. World Applied Sciences Journal. 2012;16(5):656-664.

35. Purushothaman G, Gajalakshmi G, Qairunnisa S, et al. Evaluation of hematological and biochemical parameters of magnetic field exposed albino rats. Current Trends Biotechnol Pharm. 2013;7:8873-8916.

36. Al-Uboody WSH. Effect of mobil phone electromagnetic waves on the haematological and biochemical parameters in laboratory mice (Mus musculus). Bas.J.Vet.Res. 2015;14(2):250-264.

37. Eid FA, El-Gendy AM, Zahkouk SA, et al. Ameliorative effect of two antioxidants on the liver of male albino rats exposed to electromagnetic field. Egyptian J Hospit Med. 2015;58:74-93.

38. Marzook EA, Marzook FA. Glutathione enhancer protects some biochemical and haematological parameters from the effect of electromagnetic field. Egypt J Rad Sci Applic. 2016;29(1-2):33-48.

39. Mhaibes AA, Ghadhban RF. Study effect electromagnetic field (EMF) and mobile phone radiation on some hematological, biochemical and hormonal parameters in female rats. Bas J Vet Res. 2018;17(1):155-164.

40. Stocker R, Yamamoto Y, Mcdonagh AF, et al. Bilirubin is an antioxidant of possible physiological importance. Science. 1987;235:1043-1046.

41. Singh N, Lai H. $60 \mathrm{~Hz}$ magnetic field exposures induce DNA crosslink in rat cells. Mutat Res. 1998;400:1-2.

42. Marzook EA. Effect of pulsed electromagnetic field on some biochemical and hematological parameters of female rats. Isotope Rad Res. 2006;38:1245.

43. Fathi E, Farahzadi F. Interaction of mobile telephone radiation with biological systems in veterinary and medicine. J Biomed Engin Tech. 2014;2:1.

44. Sisodia R, Rifat F, Sharma A, et al. Effects of $10 \mathrm{GHz}$ on hematological parameters in Swiss albino mice and its modulation by Prunus avium. $J$ Environ Pathol Toxicol Oncol. 2013;32:1-13.

45. Aweda MA, Gbenebitse SO, Kehinde MO. Effects of $2.45 \mathrm{GHz}$ radiofrequency exposures on normal and sickle cell erythrocytes. $\mathrm{Nig} J$ Health Biomed Sci. 2004;3(1):56-59.

46. Santana JFB, Soler MAG, Silva SW, et al. Investigation of the interaction between magnetic nanoparticles surfacecoated with carboxymethyldextran and blood cells using Raman spectroscopy. $J$ Magn Magn Mat. 2005;289:452-454.

47. Abdel-Rassoul G, Abou El-Fath O, Abou Salem M, et al. Neurobehavioral effects among inhabitants around mobile phone base stations. Neurotoxicol. 2007;28:434-440. 
48. Nadeidge C, Creanga DE, Goiceano C. Radiofrequency electromagnetic waves and paramagnetic particle effect on the red blood cells. Rom Journ Phys. 2009;54(1-2):105-114.

49. John TB. Clinical Laboratory Medicine. Kenneth D. Mc Chatchey, editors.1994. 1063p.

50. Brain DD. Red Blood Disorders. Clinical laboratory Medicine. Kenneth D. Mc Clatchey, editors. 1994. 865 p.

51. Germann, P. Study of the influence of pulsed electromagnetic radiation on blood. Red blood cells lump by mobile phone. In Independent Media Center. USA; 2004

52. El-Abiad NM, El-Aragi GM. Marzook EA. Changes in some hematological parameters and thyroid hormones in rats exposed to pulsed electromagnetic field. Arab J Nucl Sci Appl. 2007;40:269.

53. Nunia V, Sncheti G, Goyal PK. Protection of swiss albino mice against whole-body gamma irradiation by diltiazem. British J Radiol. 2007;80:77-84

54. Hassan NS. Abdelkawi SA. Changes in Molecular Structure of Hemoglobin in Exposure to $50 \mathrm{~Hz}$ Magnetic Fields. Nature and Science. 201;8(8):236-243.

55. Grawford JM. The liver and the biliary tract. Quoted from: Cotran, et al. 1994.

56. Bartsch P, Mairbäurl H, Friedmann, B. Pseudo-anemia caused by sports Ther Umsch. 1998;55(4):251-255.

57. Kula B, Drozdz M. A study of magnetic field effects on fibroblast cultures, Part 2: The evaluation of effects of static and extremely low frequency (ELF) magnetic fields on free radical processes in fibroblasts cultures, Bioelectrochem. Bioenerg. 1996;39:27-30.

58. Wagner A. The role of the laboratory in the exploration of iron metabolism. Revue de l'Acomen. 2000;6:23-27.

59. Qiu C, Fratiglioni L, Karp A, et al. Occupational exposure to electromagnetic fields and risk of Alzheimer's disease. Epidemiol. 2004;15:687-694.

60. Svedenst BM, Johanson KJ. Leukocytes and micronucleated erythrocytes in peripheral blood from mice exposed to $50-\mathrm{Hz}$ or $20-\mathrm{kHz}$ magnetic field. Electromag Biol Med. 1998;17:127-143.

61. Nakanishi K, Tajima F, Nakamura A, et al. Effect of hypobaric hypoxia on antioxidant enzymes in rats. J Physiol Lond. 1995;489:869-876.
62. Chater S, Abdelmelek H, Sakly M, et al. Effects of sub-acute exposure to magnetic field on blood hematological and biochemical parameters in female rats. Turk J Hematol. 2006;23:182-187.

63. Chater S, Abdelmelek H, Pequignot JM, et al. Effect of sub acute exposure to static magnetic field on hematologic and biochemical parameters in pregnant rats. Electromag Biol Med. 2006;25:135-144.

64. Hsu WL, Tatukawa Y, Nerishi K, et al. Longitudinal trends of total white blood cell and differential white blood cell counts of atomic bomb survivors. J Radiat Res. 2010;51:431-439.

65. Persinger MA, Glavin GB, Ossenkopp KP. Physiological changes in adult rats exposed to an elf rotating magnetic field. IntJ Biometeorol. 1972;16:163.

66. Rothman KJ. Epidemiological evidence on health risk of cellular telephones. Lancet. 2000;356:1837-1840.

67. Pashovkina M, Koev A. The liver enzymes which increase in hepatic diseases and toxic damage of liver cells boil. Radioecol. 2001;41:62-68.

68. Nafisi S, Pourfatollah AA, Mirahmadian M, et al. Acute Effect of Pulsed Electromagnetic Fields Resulting from Significant Frequencies of High and Low Triangular Waves on White Blood Cells. Global Veterinaria. 2010;5(6):362-365.

69. Bonhomme-Faivre L, Bizi E, Marion S, et al. Effect of subchronic 50 $\mathrm{Hz} 5-\mu \mathrm{T}$ magnetic field exposure on hematological parameters in mice. Electromag Biol Med. 1995;14:193-197.

70. Cabrales LB, Ciria HC, Bruzon RP, et al. ELF magnetic field effects on some hematological and biochemical parameters of peripheral blood in mice. Electromag Biol Med. 2001;20:185-191.

71. Vallejo D, Sanz P, Picazo ML. A hematological study in mice for evaluation of leukemogenesis by extremely low frequency magnetic fields. Electromag Biol Med. 2001;20:281-298.

72. Bonhomme-Faivre L. Effect of electromagnetic fields on the immune systems of occupationally exposed humans and mice. Inter $J$ Arch Environ Health. 2003;58:712-717.

73. Abd Rabou MA. Modulation of radiation injury in pregnant rats by bone marrow transplantation. IAEA. 2008;24(1):29-43.

74. Vinodha E, Raghavan S. Possible effects of cell phone radiation: An overview paper. ICES. 2015;837-841. 